\title{
Mercury accumulation in plants from contaminated arable lands in Eastern Slovakia
}

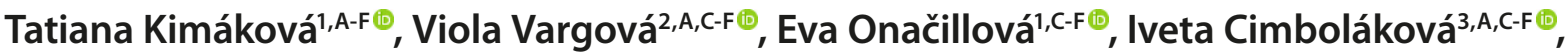 \\ Ivan Uher ${ }^{3, A, C-F \oplus}$, Peter Harich ${ }^{4, C-F} \oplus$, Jan Schuster ${ }^{5, B-F \oplus}$, Janka Poráčová ${ }^{6, A, C-F \oplus}$
}

${ }^{1}$ Department of Public Health and Hygiene, Faculty of Medicine, Pavol Jozef Šafárik University, Košice, Slovak Republic

2 1st Department of Internal Medicine, Faculty of Medicine, Pavol Jozef Šafárik University, Košice, Slovak Republic

${ }^{3}$ Institute of Physical Education and Sport, Pavol Jozef Šafárik University, Košice, Slovak Republic

${ }^{4}$ 1st Department of Stomatology, Faculty of Medicine, Pavol Jozef Šafárik University, Košice,Slovak Republic

${ }^{5}$ Department of Physical Education and Sport, Faculty of Education, University of South Bohemia, České Budějovice, Czech Republic

${ }^{6}$ Department of Biology, Faculty of Humanities and Natural Sciences, University of Prešov, Slovak Republic

A - Research concept and design, B - Collection and/or assembly of data, C - Data analysis and interpretation,

$D$ - Writing the article, E-Critical revision of the article, F- Final approval of article

Kimáková T, Vargová V, Onačillová E, Cimboláková I, Uher I, Harich P, Schuster J, Poráčová J. Mercury accumulation in plants from contaminated arable lands in Eastern Slovakia. Ann Agric Environ Med. 2020; 27(1): 29-35. DOI: 10.26444/aaem/115282

\begin{abstract}
Introduction and Objective. Contamination of soil by mercury poses several risks to human health through consumption of fruits and vegetables. In Slovakia, a high concentration of mercury is found in the soil of the Central Spiš region. The objective of the study is to measure the mercury concentrations in the parts of selected plant species and trees growing within 100 meters of a former ore processing facility.

Materials and Method. A total of 24 samples of plants, 20 samples of parts of needle-leaved trees and 9 samples of parts of broad-leaved trees were collected from soils with a high concentration of mercury. The concentration was measured by atomic absorption spectrometry in different parts of the plants: leaves - 18 species, roots - 15 species, stems - 11 species, flowers -7 species), and different parts of trees (crust -8 species, branches -8 species, needles -5 species, cones -5 species, leaves -3 species).

Results. The concentrations of mercury in the soils taken at a depth of $0.25 \mathrm{~m}$ exceeded the maximum allowed levels more than 50-times. Potatoes, parsley and carrots from these soils exceeded the maximum allowed mercury levels 6-times, 5-times and twice, respectively. The average concentrations of mercury in the roots of 2-year onions exceeded the limit more than 50 -times. The flowers of cornflower contain $18.20 \mathrm{mg}^{*} \mathrm{~kg}^{-1}$, leaves of dandelion $10.61 \mathrm{mg} \cdot \mathrm{kg}^{-1}$ and roots of plantain $6.80 \mathrm{mg}$. $\mathrm{kg}^{-1}$ of mercury. Regarding trees, the highest concentrations were found in the branches of juniper and leaves of aspen more than $1 \mathrm{mg} \cdot \mathrm{kg}^{-1}$.

Conclusions. The systematic monitoring of mercury is still very important, since it was found that the end of ore processing does not solve the issue of contamination in the Central Spiš region. Therefore, the consumption of fruits and vegetables from the areas of former ore processing facilities is not recommended.
\end{abstract}

\section{Key words}

mercury, soils, plants, environment, atomic absorption spectrometry

\section{INTRODUCTION}

Soil, formed of mineral particles, organic matter, water, air and living organisms, is characterized by the high ability of metal sorption. Absorbtion of positively charged metal ions leads over a long period to their accumulation in the soil. An increase in the input of foreign substances, especially heavy metals, results in an excessive soil burden, with an impact on the change of soil properties and on the quality of plant production. Unreasonable manipulation in agricultural primary production entails large quantities of mercury compounds into arable land, waters and oceans. Subsequently, terrestrial and marine plants and animals are enriched with mercury from the contaminated environment and mercury enters the food chain [1-4].

Address for correspondence: Tatiana Kimáková, Pavol Jozef Šafárik University in Košice, Faculty of Medicine, Department of Public Health and Hygiene, Slovak Republic

E-mail: tatiana.kimakova@upjs.sk

Received: 28.07.2019; accepted: 12.12.2019; first published: 13.01.2020
The concentrations of mercury in the atmosphere, soil, water and sediment represent a serious environmental problem. Once it becomes absorbed by humans, mercury will accumulate inside the body. Mercury poisoning can result from consuming foods containing this heavy metal, or from vapour inhalation, ingestion, injection, and absorption through the skin. The study of toxic factors of mercury in the environment on the health of the population requires a broad multidisciplinary cooperation. It is necessary to pay attention to the content of toxic chemical elements that are significant environmental contaminants of the food chain $[5,6]$.

Regarding trees, mercury deposition is higher under needle-leaved trees than broad-leaved trees, since the former trees have the higher ability to scavenge mercury. Needleleaved tress are very sensitive to air pollution and can live to be a hundred years old. From the point of view of the accumulation of heavy metals, it is obvious that there are huge amounts of these substances in the woods. Needles fall every $2-3$ years, sometimes up to 9 years. This interval is gradually decreasing due to increasingly unfavourable 
environment (influence of acid rain, exhalates, etc.). If the wood of mercury contaminated trees is used as fuel, mercury enters the atmosphere and returns back into the soil, most often in the form of an oxide which is practically insoluble in water $[7,8]$.

Regarding these issues, over 130 countries agreed to the United Nation's Minamata Convention for reducting the emission and use of mercury. The US Environmental Protection Agency has developed regulations to control mercury emissions to air, water or from wastes. There is a growing attention to mercury as a global environmental contaminant $[4,9,10]$.

Soil contamination in Slovakia. Soils ensure plant growth, provide wildlife habitat, food for humans and animals, bioenergy, clothing, pharmaceuticals, and building materials. In addition to plant production, soils also dramatically influence the Earth's atmosphere and therefore the direction of future climate change. The average contents of mercury in different types of soils from all over the world range between $0.58 \mathrm{mg} \cdot \mathrm{kg}^{-1}$ and $1.8 \mathrm{mg} \cdot \mathrm{kg}^{-1}$. The worldwide mean content is estimated at $1.1 \mathrm{mg} \cdot \mathrm{kg}^{-1}$. The phytotoxic effect of mercury on plants is associated with the occurrence of chlorosis and limiting the growth of the root system. This implies a decrease in photosynthetic pigments, enlargement of mitochondria and endoplasmic reticulum [4, 11-13].

Protecting the qualitative aspects of the agricultural land is in the interest of policies of European Union and the Slovak Republic. The European Union adopted a Thematic Strategy for Soil Protection to ensure protection and sustainable use of land, including agricultural land [14]. The legislation in Slovakia specifies limit values of chemical elements in agricultural land in $\mathrm{mg} \cdot \mathrm{kg}^{-1}$ of dry substance [15]. To assess the values of toxic chemical elements in agricultural soil, the soil samples are collected at depths to $0.2 \mathrm{~m}$ (arable lands) and to $0.1 \mathrm{~m}$ (permanent grasslands). In order to determine representative contamination for certain type of soil, an average sample area of 10 ha (at least 9 sampling sites) has to be analyzed. Limit values of chemical elements in agricultural land in $\mathrm{mg} \cdot \mathrm{kg}^{-1}$ of dry substance which were set by legislation in Slovakia [16] in 2004 are shown in Table 1. The Act on the protection and use of agricultural land specifies the limit for mercury in arable soil as $3 \mathrm{mg} \cdot \mathrm{kg}^{-1}$ of mercury.

Table 1. Limit values of risk elements in agricultural soil in $\mathrm{mg}^{\cdot \mathrm{kg}^{-1}}$ of dry substance (modified from [16])

\begin{tabular}{lccccc}
\hline Soil type & As & $\mathrm{Cd}$ & $\mathrm{Cr}$ & $\mathrm{Hg}$ & $\mathrm{Pb}$ \\
\hline Sandy, loamy sand & 10 & 0.4 & 50 & 0.15 & 25 \\
\hline Sandy loam, loam & 25 & 0.7 & 70 & 0.5 & 70 \\
\hline Clay loam, loam & 30 & 1 & 90 & 0.75 & 115
\end{tabular}

Mercury content in the soils of Slovakia is higher in comparison with soils worldwide. They are affected by the long-term process of mercury accumulation in soils, by the fossil fuels (more than 150-year impact), the mercury emission of metallurgy facilities and the applied chemicals in the soils. Geochemical anomalies are manifested in the areas with mercury ores. In Eastern Slovakia, high concentration of mercury were found in the soil of the Central Spiš region (Gelnica district and Spišská Nová Ves district). Mercury contamination also affects the peaks in the High Tatras and Low Tatras, Small and Big Fatra and certain border mountains. This fact indicates the cross-contamination of soils in a northwest flow [17-25].

In 1843, a modern smelter began copper production in Kluknava village, a part of Štefanská Huta in Spišská Nová Ves district. In 1889, the first separation of silver from copper in Slovakia was performed here. The ores were mined in the mountains. They were polymetallic and contained a significant amount of mercury which was also produced by the facility which was closed in 1897 due to the poor economic situation in the region. Although the facility ceased operating more than a hundred years ago, a mercury contamination of soils remains. The mercury enters the environment as a metal in the form of vapours condensed in the area, depending on the ambient temperature and the weather. The mercury can also get into the environment as a vapour since the mercury vapor pressure is significant at ambient temperatures. In the 1940 s, it was possible to collect small droplets of mercury on a hillside about 50 meters from the old facility. Today, the mercury is present in compounds in the form of sulfide, sulfate, nitrate and chloride [26-29].

In 1895 , an iron ore smelting and mercury production plant (Želba Company) was founded in Rudňany near Spišská Nová Ves. Although production ceased in 1992, contamination of the environment (especially soils) will take several years to disperse. The former mercury company in Rudnany significantly contributed to the fact that the areas of the Central Spiš (Gelnica district and Spišská Nová Ves district) are considered as the most affected areas in the Slovak Republic. Rudňany is strongly contaminated by mercury with concentrations in soils up to $130 \mathrm{mg} \cdot \mathrm{kg}^{-1}$ [26-29].

Klinda et al. [30] indicate that in 1991, the limit value for mercury in soil samples was exceeded in 301 samples (6.6\%) from 4,578 soil samples. The highest average mercury concentrations were recorded in the Spišská Nová Ves district. The State Geological Institute of Dionýz Štúr in Bratislava explored the arable soils in 100 villages of Spišsko-Gemerské Rudohorie in order to detect concentrations of 10 studied metals. The mercury concentration in the soil was $173.4 \mathrm{mg}$. $\mathrm{kg}^{-1}$ in the village of Matejovce and $173.5 \mathrm{mg} \cdot \mathrm{kg}^{-1}$ in Rudňany. Mercury concentrations of $44.24 \mathrm{mg} \cdot \mathrm{kg}^{-1}$ were described in the soil from the mining area at the Vel'ká Studňa locality [31].

\section{OBJECTIVES}

1. To measure the mercury concentrations in the parts of selected plant species growing very close to the former ore processing facility by a method of flameless atomic absorption spectrometry.

2. To measure the mercury concentrations in the parts of needle-leaved and broad-leaved trees which grow within 100 meters by the method of flameless atomic absorption spectrometry.

3. To make a comparison of results from similar studies with those obtained in the current study.

\section{MATERIALS AND METHOD}

Collection of plant and tree samples. The concentrations of mercury were analyzed on the samples of plants obtained in areas with a high concentration of mercury in the soil. 
The plants were collected in the village Kluknava (Fig. 1), part Štefanská Huta in the district Spišská Nová Ves. Concentrations of mercury per $1 \mathrm{~kg}$ of soil were found in the samples taken from soil to a depth of $0.25 \mathrm{~m}$. The soils in this are exceeded the maximum allowed mercury level of $3 \mathrm{mg} \cdot \mathrm{kg}^{-1}$ more than 50 -times. The content of this metal varies in a relatively wide range depending on the distance from the ruins of the former facility. The plants contained a substantial concentration of mercury, since the plant roots dissolve the insoluble form of mercury through their secretions. The plants then absorb the mercury together with nutrients. A similar phenomenon occurs in the absorption of soluble fertilizer such as superphosphate.

The concentration of mercury was measured in different parts of the plants: leaves, roots, stems and flowers. A total of 24 species of plants were collected from the areas with a high concentration of mercury in the soil. Of particular interest were species of plantain, chamomile, tansy, dill, Shepherd's purse, sorrel, dandelion, nettle, dead nettle, mullein, chives, carrots, parsley, one and two-year old onion, kohlrabi, sunflower, poppy, cornflower, thistle, apple, willow, slippery jack, and potatoes. The concentration of mercury was measured three times in different parts of the plants: leaves - 18 species, roots - 15 species, stems - 11 species, flowers -7 species.

In addition, samples of parts of needle-leaved trees (crust - 5 species, branches -5 species, needles -5 species, cones - 5 species), and samples of broad-leaved trees parts (crust - 3 species, branches - 3 species, leaves -3 species) were collected. No roots of trees were collected due to technical difficulties. Trees are incomparably larger compared to other plants, therefore samples were taken from several parts of the tree. The measured values are the average of the samples taken.

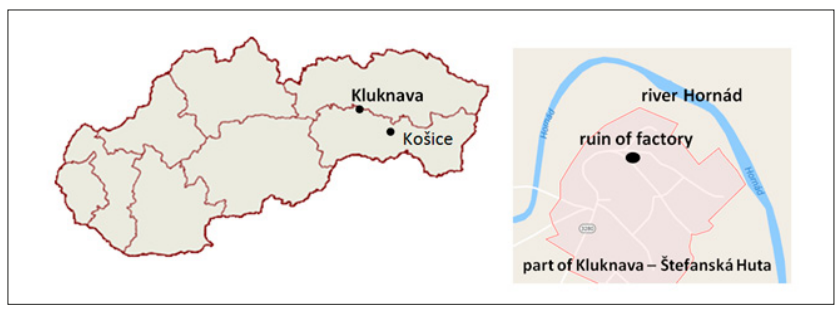

Figure 1. Location of former facility near the river Hornád

Method of mercury determination. The mercury content of the individual plant parts was determined by TMA 254 (Trace Mercury Analyzer) from the Czech Technical University in Prague. The Atomic Absorption Spectrophotometer TMA is a mercury analyzer capable of determining a minimum of $0.1 \mathrm{ng}$ of mercury in the test sample. It is possible to determine mercury in waters, solid and liquid biological materials, without the need to dissolve the sample. There is also no secondary contamination of the sample with the used chemicals. The errors that occur in the determination of mercury in various samples are most often caused by sampling, storage, transport and processing [32].

To determine the mercury concentration in individual plants, the analytical method was used for the determination of mercury by flame-free atomic absorption spectrometry (AAS). The instrument is capable of analyzing directly samples containing up to $40 \mathrm{ng}$ mercury in the first range. If the mercury content in the sample exceeds $40 \mathrm{ng}$, the instrument will automatically measure the amount of $\mathrm{Hg}$ in the second range up to $400 \mathrm{ng}$. TMA 254 has advantageous determination, reproducibility values and allows working over a wider concentration range. More details about the principles of this analyzer can be found in $[32,33]$.

The calibration solution was prepared from metallic polarographic mercury. Weighted $1.0 \mathrm{~g}$ of metallic mercury of $99.99 \%$ purity were used, then placed it into a calibrated flask $1 \mathrm{dm}^{3}$, to which was added $30 \mathrm{ml}$ of concentrated nitric acid $\mathrm{HNO}_{3}$ p.a., dissolved, supplemented with distilled water. This provided a standard mercury solution of $1,000 \mathrm{mg} \cdot \mathrm{l}^{-1}$. The calibration solution was prepared by diluting the stock solution, thus $1 \mathrm{ml}$ contains $1 \mathrm{mg}$ of mercury. From a standard mercury standard solution of $1,000 \mathrm{mg} \cdot \mathrm{l}^{-1}, 1 \mathrm{ml}$ was pipetted into $1,000 \mathrm{ml}$ volumetric flask and made up to the mark with deionized water. A solution was obtained with a concentration of $1 \mu \mathrm{l}$, which corresponds to $1 \mathrm{ng}$ of mercury.

Evaluation of results. The results were evaluated by Regulations of the Government of the Slovak Republic No. 499/2008 Coll. and No. 121/2009 Coll. [34], which present the limit values of risk elements in fruit, vegetables and ware potatoes (Tab. 2, Tab. 3).

Table 2. Limit values of risk elements in fruit samples [34]

\begin{tabular}{lc}
\hline Chemical element & $\begin{array}{r}\text { Maximum level of total chemical elements } \\
\text { in fruits }\left(\mathrm{mg}^{*} \mathrm{~kg}^{-1}\right)\end{array}$ \\
\hline Lead $(\mathrm{Pb})$ & $\mathrm{M}$ \\
\hline Cadmium $(\mathrm{Cd})$ & 0.03 \\
\hline Mercury (Hg) & $\mathbf{0 . 0 3}$ \\
\hline Arsenic (As) & 0.5 \\
\hline
\end{tabular}

Table 3. Limit values of risk elements in vegetables and ware potatoes [34]

\begin{tabular}{lcc}
\hline $\begin{array}{l}\text { Chemical } \\
\text { element }\end{array}$ & $\begin{array}{c}\text { Maximum level of total } \\
\text { chemical elements }\left(\mathrm{mg}^{\circ} \mathrm{kg}^{-1}\right)\end{array}$ & Food \\
\hline 0.1 & $\begin{array}{c}\text { Stem and root vegetables, except } \\
\text { celery, ware potatoes }\end{array}$ \\
\hline Cadmium (Cd) & 0.2 & Leaf vegetables, fresh herbs, celery \\
\hline Lead (Pb) & 0.05 & Other vegetables \\
\hline & 0.1 & Other vegetables, ware potatoes \\
\hline Mercury (Hg) & 0.3 & Broccoli, green leafy vegetables \\
\hline Copper (Cu) & $\mathbf{0 . 0 2}$ & Ware potatoes \\
\hline $\mathbf{0 . 0 5}$ & 3 & Vegetables \\
\hline Nickel (Ni) & 10 & Ware potatoes \\
\hline & 0.5 & Vegetables \\
\hline
\end{tabular}

\section{RESULTS}

The concentrations of mercury in the samples of plants from the areas with a high concentration of mercury in the soil were analyzed. By using a TMA 254 atomic absorption spectrometer, it was found that mercury concentrations in plants from trace values to concentrations exceeded the limits more than 1,000-fold. The concentration of mercury was measured in different parts of the plants (leaves, roots, stems, flowers). Three measurements were made for each individual 
part of plant. The average value is presented in the following: average mercury concentrations in the leaves of plants, excluding dandelion, ranged from $0.14 \mathrm{mg} \cdot \mathrm{kg}^{-1}-3.35 \mathrm{mg}$. $\mathrm{kg}^{-1}$; the average concentration of mercury in the leaves of dandelion - $10.61 \mathrm{mg} \cdot \mathrm{kg}^{-1}$ (Fig. 2).

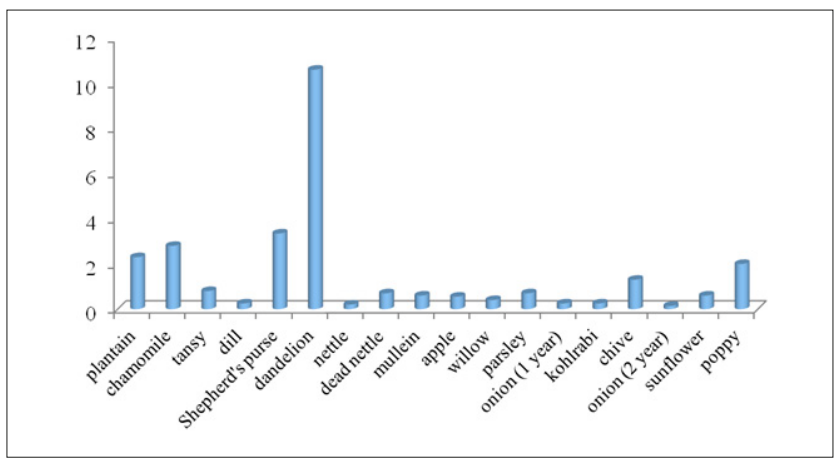

Figure 2. Concentrations of mercury in leaves of plants in $\mathrm{mg} \mathrm{kg}^{-1}$.

The average concentrations of mercury in the roots of plants, excluding plantain and tansy, ranged from $0.02 \mathrm{mg} \cdot \mathrm{kg}^{-1}$ $-2.80 \mathrm{mg} \cdot \mathrm{kg}^{-1}$. The average concentrations of mercury in the roots of plantain and tansy were $6.83 \mathrm{mg} \cdot \mathrm{kg}^{-1}$ and $4.21 \mathrm{mg} \cdot \mathrm{kg}^{-1}$, respectively. The lowest average values of mercury were obtained in the roots of carrot and kohlrabi (below limit $\left.0.05 \mathrm{mg} \cdot \mathrm{kg}^{-1}\right)$. The average concentrations of mercury in the roots of parsley, one-year onion and two-year onion were exceeded limit 4-times, 8-times and 56-times, respectively (Fig. 3).

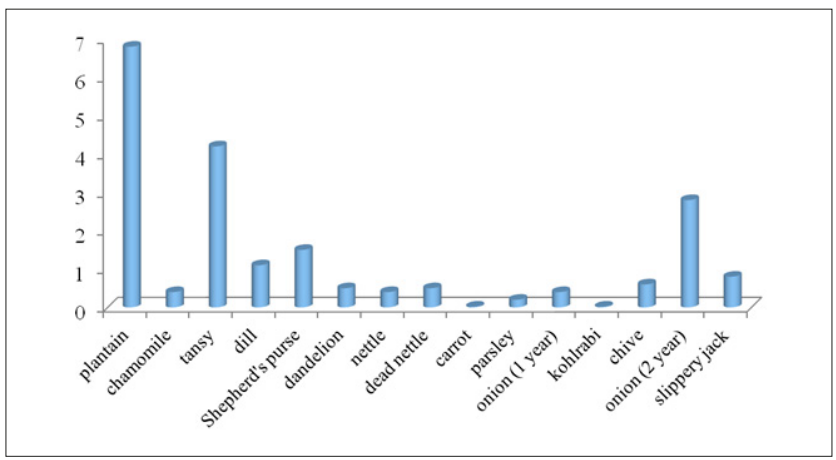

Figure 3. Concentrations of mercury in roots of plants in $\mathrm{mg} \mathrm{kg}^{-1}$

The average concentrations of mercury in the stems of plants, excluding dandelion, ranged from $0.01 \mathrm{mg} \cdot \mathrm{kg}^{-1}-$ $1.53 \mathrm{mg} \cdot \mathrm{kg}^{-1}$. Mercury in dandelion stems has the highest average concentration $-6.25 \mathrm{mg} \cdot \mathrm{kg}^{-1}$ (Fig. 4).

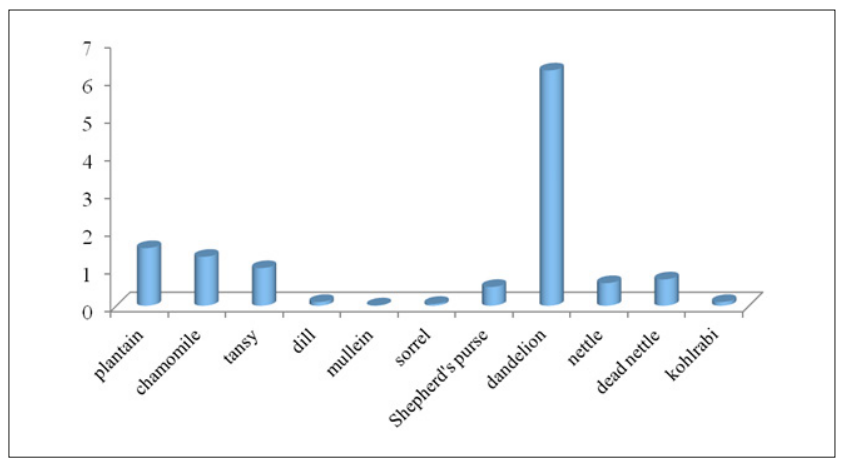

Figure 4. Concentrations of mercury in stems of plants in $\mathrm{mg} \mathrm{kg}^{-1}$
The average concentrations of mercury in the flowers of plants, excluding cornflower, ranged from $0.28 \mathrm{mg} \cdot \mathrm{kg}^{-1}$ to $4.29 \mathrm{mg} \cdot \mathrm{kg}^{-1}$. Mercury in cornflower had the highest average concentration - $18.2 \mathrm{mg} \cdot \mathrm{kg}^{-1}$ (Fig. 5).

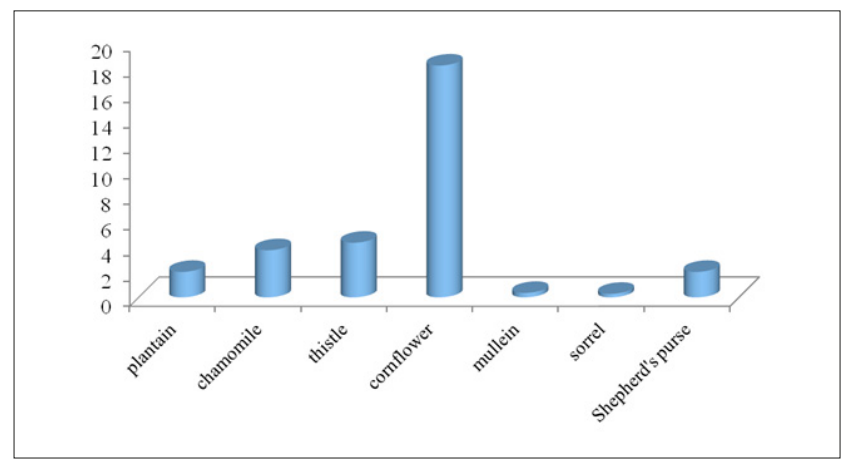

Figure 5. Concentrations of mercury in flowers of plants in $\mathrm{mg}^{\cdot} \mathrm{kg}^{-1}$

Regarding potatoes, the highest concentrations of mercury were measured in its fruit. The average mercury concentration was $0.12 \mathrm{mg} \cdot \mathrm{kg}^{-1}$, which exceeded the maximum allowed level 6-times. The fruits of carrots have the average mercury concentration $0.11 \mathrm{mg} \cdot \mathrm{kg}^{-1}$, which exceeded the maximum allowed level 2-times. The fruits of parsley have the average mercury concentration $0.23 \mathrm{mg} \cdot \mathrm{kg}^{-1}$, which exceeded the maximum allowed level 5-times.

The average concentrations of mercury in the parts of needle-leaved trees range from $0.12 \mathrm{mg} \cdot \mathrm{kg}^{-1}$ to $1.38 \mathrm{mg} \cdot \mathrm{kg}^{-1}$. The highest average concentrations were measured in the branch of juniper, crust of juniper and needle of larch. The lowest average concentrations were measured in the cone of larch and cone of fir. Regarding fir and larch, the highest average concentrations of the mercury were found in the needles and branches, the least in the cone. Regarding pine, the lowest average mercury concentrations were found in the needles (Tab. 4).

Table 4. Concentration of mercury in parts of needle-leaved trees in $\mathrm{mg} \cdot \mathrm{kg}^{-1}$

\begin{tabular}{lcccc}
\hline & Needle & Branch & Crust & Cone \\
\hline Fir & 0.573 & 0.434 & 0.211 & 0.120 \\
\hline Larch & 1.312 & 0.898 & 0.198 & 0.117 \\
\hline Pine & 0.290 & 1.052 & 1.025 & 0.910 \\
\hline Spruce & 0.258 & 0.131 & 0.689 & 0.270 \\
\hline Juniper & 0.148 & 1.383 & 1.323 & - \\
\hline
\end{tabular}

The average concentrations of mercury in the parts of broad-leaved trees range from $0.11 \mathrm{mg} \cdot \mathrm{kg}^{-1}-1.87 \mathrm{mg} \cdot \mathrm{kg}^{-1}$. Regarding all 3 species, the highest average concentrations were found in the leaves of these trees. The highest average concentration was measured in the leaf of aspen, 4-times higher than in the leaf of birch and 6-times higher than in the leaf of hornbeam. The concentration in the leaf of aspen was 16-times higher than in the branch of aspen and 17-times higher than in the crust of aspen. The lowest average concentration was measured in the crust of aspen. The average values of mercury concentrations in the parts of broad-leaved trees are presented in Table 5. 
Table 5. Concentration of mercury in parts of broad-leaved trees in $\mathrm{mg} \cdot \mathrm{kg}^{-1}$

\begin{tabular}{lccc}
\hline & Crust & Branch & Leaf \\
\hline Hornbeam & 0.121 & 0.082 & 0.312 \\
\hline Birch & 0.399 & 0.323 & 0.421 \\
\hline Aspen & 0.108 & 0.114 & 1.873 \\
\hline
\end{tabular}

\section{DISCUSSION}

The impact of mercury on health is the subject of study in recent papers by the authors of the current study [17-24]. Regarding their findings, the authors emphasize that the spatial distribution of mercury in soils is the function of distance from the former ore facility. Higher concentration of mercury were found in the roots of onion, compared with the leaves of onion (in the area with high concentration of mercury in soil of region Central Spiš). For chives and dandelion, higher values were measured in the leaves than in the roots.

The highest concentrations were observed in perennial plants (weeds) of the families Asteraceae, Brassicaceae and Plantaginaceae. The results showed that the mercury was absorbed by the plants from soil, and it must be emphasized that the plant/soil system is influenced by soil reaction, soil organic matter and genotypes of the studied plants. These belonged to different families, therefore the concentration of mercury in their parts is hard to compare with one another. However, the mercury concentrations have comparable trends in plants belonging to the same families which have the same common parts.

In the obtained results, the distribution of mercury in the different parts of needle-leaved trees varied, although they grew in a group approximately $50 \mathrm{~m}$ from the mercury source. Regarding fir and larch, the highest average concentrations of the mercury were found in the needles and branches, the least in the cone. The opposite results were found in pin where the lowest average mercury concentrations were found in the needles, although the needles withstand frost and fall in the autumn. The highest concentrations of mercury were found in the crust and branches of pine and juniper.

In the broad-leaved trees, the highest average mercury concentrations occurred in the leaves, which are peripheral parts of the tree. Thus, a portion of mercury concentration is also removed from tree by the falling of these leaves in the autumn. However, they fall in the immediate vicinity of the tree or surrounding trees where they rot, and the mercury compounds are released from the leaf structure back to the roots and then again absorbed. Several times higher values were measured in aspen leaves, although this tree grew in the same place as the hornbeam and birch. It is assumed that the transport of mercury towards the leaves is affected by the fact that aspen grows faster than other tree, the wood is thin and contains much more water than birch and hornbeam.

Palušová and Ursínyová [35] found that the average value of mercury in the analyzed fruits was $0.019 \mathrm{mg} \cdot \mathrm{kg}^{-1}$, which was lower in comparison with vegetables, which ranged from $0.043 \mathrm{mg} \cdot \mathrm{kg}^{-1}-0.058 \mathrm{mg} \cdot \mathrm{kg}^{-1}$. The highest levels were found in the fruit of vegetables, and the lowest values in their roots.

Szprengier-Juszkiewicz [36] indicate that the Polish population receives more than half of the mercury $(63.4 \%)$ from plant foods (fruits and vegetables $22.2 \%$, potatoes 19.3
$\%$ and wheat $18.5 \%)$. Cibulka et al. [37] found high levels of mercury in pepper fruit, up to $0.650 \mathrm{mg} \cdot \mathrm{kg}^{-1}$. They found three times less mercury content in the underground parts of plants in comparison with the vegetative parts of plants. It appears that air emissions are also an important source of mercury pollution of plants [38].

Pavlík et al. [39] indicate exceeded values of mercury in onion from the Central Spiš region. Hronec [40] presents that the mercury concentration in different parts of the plant decreases in the following order: leaves, stems, grains, tubers, and the fruits. In general, the accessibility of mercury in soil to plants is low, the tendency is accumulation in the roots which are the barrier to mercury intake by plants. The aerial parts of plants absorb mercury directly from the atmosphere [40].

The studies undertaken do not explain the mechanism of entry and mercury concentrations in plant organs. The risk factors from mercury in soils are increased by extreme acidity of the soils. During the spring months, the proportion of mobile mercury compounds increases at low temperatures and increased humidity. Land reclamation can be implemented by using organic substrates which decrease the concentrations of heavy metals $(\mathrm{Cr}, \mathrm{Pb}, \mathrm{As}, \mathrm{Cd}, \mathrm{Hg}$ ), with a beneficial effect on the reduction of heavy metals in cultivated plants (for copper - $49.3 \%-70.8 \%$; for mercury - $37.3 \%-42.8 \%)$ [41].

Hlodák et al. [42] presented higher mercury concentration in the above-ground parts of strawberries $\left(0.73 \mathrm{mg} \cdot \mathrm{kg}^{-1}\right)$ in the Spišská Nová Ves region, indicating its ability to accumulate mercury in parts of strawberries. Low levels of mercury were found in the roots of beet $\left(0.016 \mathrm{mg} \cdot \mathrm{kg}^{-1}\right)$, roots of parsnips $\left(0.019 \mathrm{mg} \cdot \mathrm{kg}^{-1}\right)$ and roots of parsley $\left(0.029 \mathrm{mg} \cdot \mathrm{kg}^{-1}\right)$. The values in the roots of carrot $\left(0.052 \mathrm{mg}^{\cdot \mathrm{kg}^{-1}}\right)$ exceeded the limits.

Richardson and Friedland found that needle-leaved forest soils have higher mercury concentrations than in broadleaved forest soils in the mountains of New Hampsire and Vermont in USA. They observed that the wood of needleleaved trees had higher mercury concentrations than broadleaved trees [43]. Laacouri et al. and Obrist et al. explored the seasonal dynamics of the mercury concentration of leaves. They found that the concentrations were affected by the placement and age of the leaves $[44,45]$.

De Temmerman et al. [46] indicate that under experimental setting, there is no evidence of any root uptake of mercury in growing leafy vegetables in a peat based substrate. Yu et al. [47] examined the role of soil mercury in vegetable absorbtion. Enrichment ability was higher in green pepper, spinach, cabbage and Chinese cabbage. In Germany [48], soil mercury levels exceeded the maximum regulation limits in bean roots and carrot shoots planted in gardens situated in the area of a mine dump. Li et al. [49] reported that soil, vegetable, and grain samples collected from field locations within $10 \mathrm{~km}$ distance from coal-fired power plants in China, had significantly higher mercury concentrations than the samples purchased from a grocery store away from any power plant. $79 \%$ of vegetable samples and $67 \%$ of grain samples exceeded the upper limit of allowable mercury level. Similar results can be found in [50], which show that the spatial distribution of mercury in soils is a matter of the distance from a coal-fired power plant in the USA. 


\section{CONCLUSIONS}

Leaves, stems, roots and flowers are integral parts of the plants that are adapted to perform specific functions. The aim of this study was to measure and to compare the concentrations of mercury in these parts of selected plant and tree species growing close (within $100 \mathrm{~m}$ ) of a former ore processing plant, which ended its production approximately 120 years ago. The levels of mercury in soils from this area exceeded the maximum allowed mercury levels more than 50-times. Similar levels of mercury in the soil were also measured in Rudňany, where mercury was produced near the city of Spišská Nová Ves approximately 30 years ago. It was found that most of the mercury in these soils was present in the form of sulphide or sulfate.

Mercury in the samples of plants in the current study was absorbed mainly from the soil. The relation between soil and plants is influenced by soil reaction, soil organic matter and plant genotype. Caring for the maintenance of fertile and hygienically safe soil is important, since the impurities can have a long-lasting or permanent character in the soil. Soil is formed by mineral particles, organic matter, water, air and living organisms. Increased acidity of precipitation has also recently contributed significantly to the release of heavy metals from soil. In general, if soil acidification increases, the risk of metal accumulation increases. Data on the development of soil contamination and on the level of soil plant contamination should be provided to the public, since our food is produced in our soils.

It can be concluded that the increasing concentration of mercury in soil leads to increase the absorption of mercury by plants. The spatial distribution of mercury in soils depends on the distance from the former ore processing plants. Reducing the consumption of fruits and vegetables from the areas with high concentrations of mercury in soils is recommended, while fruits and vegetables should be consumed from proved soil sources.

\section{Acknowledgement}

The study was partially supported by the Scientific Grant Agency of the Ministry of Education of the Slovak Republic and the Slovak Academy of Sciences under contract VEGA 1/0783/18: Biochemical, physiological and haematological status in selected species of hunting game. The paper was also partially supported by the Cultural and Educational Grant Agency of the Ministry of Education, Science, Research and Sport of the Slovak Republic under contract KEGA 005UPJŠ4/2019: Analysis of Lifestyle Risk Factors of University Students and Students of the Third Age University, and under contract KEGA 018PU-4/2018: Innovation of methods and forms of teaching the subject of biochemistry.

\section{REFERENCES}

1. Bencko V, Wagner V. Metals, metalloids and immunity. Methodological approaches and group diagnostics. Centr Europ J Occup Environ Med. 1995; 1(4): 327-337.

2. Bencko V, Novák J, Suk M (Eds.) Health and natural conditions (Medicine and Geology). Praha: Dolin, 2011. (In Czech)

3. Nance P, Patterson J, Willis A, et al. Human health risks from mercury exposure from broken compact fluorescent lamps. Regul Toxicol Pharmacol. 2012; 62(3): 542-552.

4. Xu J, Bravo AG, Lagerkvist A, et al. Sources and remediation techniques for mercury contaminated soil. Environ Int. 2015; 74: 42-53.
5. Kottferová J, Koréneková B. The effect of emissions on heavy metals concentrations in cattle from area of on industrial plant in Slovakia. Arch Environ Contam Toxicol. 1995; 29(3): 400-405.

6. Fazekašová D, Poráčová J. Sustainable agriculture. Prešov: Faculty of Humanities and Natural Sciences, University of Prešov, 1999. (In Slovak)

7. Drenner RW, Chumchal MM, Jones CM, et al. Effects of mercury deposition and coniferous forests on the mercury contamination of fish in the South Central United States. Environ Sci Technol. 2013; 47: 1274-1279.

8. Tchounwou PB, Yedjou CG, Patlolla AK, et al. Heavy metal toxicity and the environment. Mol Clin Environ Toxicol. 2012; 101: 133-164.

9. EPA (U.S. Environmental Protection Agency). Laws and Regulations, 2013, https://www.epa.gov/laws-regulations (access: 2019.06.18)

10. UNEP (The United Nations Environment Programme). Technical background report for the global mercury assessment 2013. Arctic Monitoring and Assessment Programme, Oslo, Norway/UNEP ChemicalsBranch, Geneva, Switzerland; 2013.

https://www.amap.no/documents/download/1265/inline (access: 2019.06.18)

11. Kabata-Pendias A. Trace elements in soils and plants. CRC Press, 2010.

12. Almeida ILS, Oliveira MDR, Silva JBB, et al. Suitable extraction of soils and sediments for mercury species and determination combined with the cold vapor generation atomic absorption spectrometry technique. Microchem J. 2016; 124: 326-330.

13. Weil RR, Brady NC, Weil RR. The nature and properties of soils. Pearson, 2016.

14. Communication from the Commission to the Council, the European Parliament, the European Economic and Social Committee and the Committee of the Regions - Thematic Strategy for Soil Protection. $\mathrm{COM} / 2006 / 0231,2006$,

h t t p s : / / e u r - lex.e uropa.e u / le ga l-content/EN / TXT/?uri=CELEX:52006DC0231 (access: 2019.07.27)

15. Palšová L. Legislation on The Protection of Agricultural Land in the context of the implementation of the Thematic Strategy for Soil Protection in Slovak Conditions. EU Agrarian Law. 2014; 3(1): 24-30.

16. Act No. 220/2004 Coll. on the conservation and use of agricultural land and amending Act No. 245/2003 Coll. concerning integrated pollution prevention and control.

17. Kimáková T. Mercury cycle in nature regarding living organism. INFOVET. 1999; 6(4): 36-38. (In Slovak)

18. Kimáková T, Andruch V, Kalavský F. Mercury content in seafood. Proceedings of 2nd International Conference on Mineralurgy and Environmental Technologies; Herlany, Slovakia. Košice: Technical University in Košice; 2001. (In Slovak)

19. Kimáková T, Bernasovská K. The Mercury Concentration in Particular Parts of Taraxacum officinale (Dandelion) in different Areas of Slovakia. Planta Med. 2007; 73(9): 907.

20. Kimáková T, Bernasovská K. Fish consumption. Hygiene. 2007; 52(3): 77-79. (In Slovak)

21. Kimáková T, Kalavský F. Mercury and its occurrence in individual parts of selected plants of middle Spiš. In: Using experimental methods to protect and promote the health of the population: Proceedings. Košice: Pavol Jozef Šafárik University in Košice, 2010. pp. 165-171. (In Slovak)

22. Kimáková T, Poráčová J. Mercury content in selected organs of potato (Solanum tuberosum) plants in the areas with elevated mercury soil content in Slovakia. In: Epidemiol Suppl. 2011; 22(1): 290.

23. Kimáková T, Cimboláková I, Farkašová Iannaccone S, et al. Environment and its ethical aspects. Košice: Pavol Jozef Šafárik University in Košice, 2015. (In Slovak)

24. Kimáková T. The occurence of mercury in one of the part in East Slovakia. In: TOXCON 2015. Brno: Tribun EU, 2015. pp. 75.

25. Čurlík J, Šef̌́ík P. Geochemical atlas of the Slovak Republic. Land. Ministry of Environment of the Slovak Republic, 1999. (In Slovak)

26. Maňkovská B. Mercury concentrations in forest trees from Slovakia. Water Air Soil Pollut. 1996; 89: 267-275.

27. Dombaiová R. Mercury and methylmercury in plants from differently contaminated sites in Slovakia. Plant Soil Environ. 2005; 51(10): 456463.

28. Melicherčík M, Melicherčíková D. Impact of the environment and the effects of substances on the human organism. Banská Bystrica: Matej Bel University in Banská Bystrica, 2010. (In Slovak)

29. Hauck M, Huneck S. Lichen Substances Affect Metal Adsorption in Hypogymnia physodes. J Chem Ecol. 2007; 33: 219-223.

30. Klinda J, Lieskovská Z, et al. State of the Environment Report of the Slovak Republic 1999. Banská Bystrica: Ministry of Environment of the Slovak Republic and Slovak Environmental Agency, 1999. (In Slovak) 
31. Dadová J, Andráš P, Kupka J, et al. Mercury contamination from historical mining territory at Malachov Hg-deposit (Central Slovakia). Environ Sci Pollut Res Int. 2016; 23(3): 2914-2927.

32. AMA 254 Advanced Mecury Analyzer Specification Sheet, 2008, http:// www.usbioecuador.com/descargas/AMA254-ht.pdf (access: 2019.05.28)

33. Kimáková T, Kuzmová L, Nevolná Z, et al. Fish and fish products as risk factors of mercury exposure. Ann Agric Environ Med. 2018; 25(3): 488-493.

34. Regulation of the Government of the Slovak Republic No. 499/2008 and No. 121/2009 Coll.

35. Palušová $\mathrm{O}$, Ursínyová $\mathrm{M}$. Mercury residues in the environment and food components of the West Slovakia Region. Čs Hyg. 1989; 34(5): 274-279. (In Slovak)

36. Szprengier-Juskiewicz T. Pobranie rteci wraz z żywnóścią zwierzęcego pochodzenia w Polsce. Med Wet. 1996: 234-237.

37. Cibulka J, et al. Lead, cadmium and mercury cycling in the biosphere. Praha: Academia, 1991. (In Czech)

38. Kottferová J, Bachňáková I, Patočková L. Mercury levels in natural spices and in saromex. In: Proceedings XI. Hygiena Alimentorium. Vysoké Tatry, Starý Smokovec, 1990: pp. 126. (In Slovak)

39. Pavlík V, Sommer A, KočiščákE, et al. Ecological problems in industrially exposed regions of Eastern Slovakia in relation to agriculture. Nitra: Research Institute of Animal Production, 1997. (In Slovak)

40. Hronec O. Exhales - Soil - Vegetation. Bratislava: Slovak Agricultural and Food Chamber, 1996. (In Slovak)

41. Godbold DL, Huttermann A. Inhibition of photosynthesis and transpiration in relation to mercury - induced root demage in spruce seedlings. Physiol Plant. 1988; 74(2): 270-275.
42. Hlodák M, Matúš P, Urík M, et al. Biogeochemistry of mercury in a soil-plant system in an anthropogenic contaminated area. Chem listy. 2016: 109: 385-389 (In Slovak).

43. Richardson JB, Friedland, AJ. Mercury in coniferous and deciduous upland forests. Biogeosciences. 2015; 12: 6737-6749.

44. Laacouri A, Nater EA, Kolka RK. Distribution and uptake dynamics of mercury in leaves of common decidouos tree species in Minnesota, USA. Environ Sci Technol. 2013; 47(18): 10462-10470.

45. Obrist D, Johnson DW, Edmonds RL. Effects of vegetation type on mercury concentrations and pools in two adjacent coniferous and deciduous forests. J Plant Nutr Soil Sc. 2012; 175:68-77.

46. De Temmerman L, Waegeneers N, Claeys N, et al. Comparison of concentrations of mercury in ambient air to its accumulation by leafy vegetables: An important step in terrestrial food chain analysis. Environ Pollut. 2009; 157: 1337-1341.

47. You H, Li J, Luan Y. Meta-analysis of soil mercury accumulation by vegetables. Sci Rep. 2018; 8(1): 1261

48. Antoniadis V, Shaheen SM, Boersch J, et al. Bioavailability and risk assessment of potentially toxic elements in garden edible vegetables and soils around a highly contaminated former mining area in Germany. J Environ Manage. 2017; 186: 192-200.

49. Li R, Wu H, Ding J, et al. Mercury pollution in vegetables, grains and soils from areas surrounding coal-fired power plants. Sci Rep. 2017; 7: 46545 .

50. Filippelli GM, Risch M, Laidlaw MA, et al. Geochemical legacies and the future health of cities: A tale of two neurotoxins in urban soils. Elementa-Sci Anthrop. 2015: 3: 000059. 